\title{
The re-design of a fourth year Bachelor of Education programme using the Constructive Alignment Approach
}

\author{
Melanie B. Luckay* \\ doi: http://dx.doi.org/10.18543/tjhe-6(1)-2018pp143-167
}

Received: 02.08.2018

Accepted: 31.10 .2018

\begin{abstract}
The focus of this article is on the re-design of a fourth year Bachelor of Education (B.Ed) programme at the University of the Western Cape (UWC). Due to the changes in teacher qualifications, as outlined in the 2015 Minimum Requirements for Teacher Education Qualification (MRTEQ) policy document, Higher Education Institutions were required to adapt their Initial Teaching Education (ITE) programmes to meet the requirements of the new policy document. This article describes the use of a backward mapping approach, in conjunction with the application of a constructive alignment framework, used by the education faculty at UWC to adjust the teaching and learning in the B.Ed programme to address the outcomes and standards required by the MRTEQ policy document. Given the type of student enrolled at UWC, the article provides a discussion on the challenges involved in developing a programme for students who might not have been adequately prepared for their tertiary studies due to the disadvantaged school contexts they come from. The article thus provides a reflective discussion on the challenges involved in the re-design process that used the pre-service teacher competencies expected at the end of the B.Ed programme at UWC, to develop the teaching and learning programme and assessment tasks for the fourth year B.Ed course.
\end{abstract}

Keywords: Initial Teacher Education; Bachelor of Education programme; backward mapping; constructive alignment; Higher Education Institutions; Curriculum; Education Re-design.

* Melanie B. Luckay (mluckay@uwc.ac.za), PhD, is a senior lecturer in the Faculty of Education at the University of the Western Cape (UWC), Cape Town, South Africa.

More information about the author is available at the end of this article.

Acknowledgements: This work was carried out at UWC and Deusto International Tuning Academy (DITA) at the University of Deusto, Bilbao, Spain, and was financially supported by Tuning Short-Term Visit Scholarship [http://tuningacademy.org/short-term-visits-call/]. 


\section{Introduction}

The focus of this article is on exploring the application of a constructive alignment framework ${ }^{1}$ for the re-design of the fourth year education programme at the University of the Western Cape (UWC). Following the publication of the 2015 Minimum Requirements for Teacher Education Qualification (MRTEQ) document ${ }^{2}$ the UWC faculty staff identified the need to adapt the existing Bachelor of Education (B.Ed) programme at UWC to meet the requirements of MRTEQ. The MRTEQ policy document provides the basis for the construction of core curricula for Initial Teacher Education (ITE). This article describes this process and discusses the constructive alignment (CA) approach as a framework for adjusting teaching and assessment programmes in higher education institutions (HEIs) to address the proposed outcomes and standards required by the MRTEQ policy document.

Given the challenge of adapting the B.Ed programme to align with the MRTEQ document, the UWC staff within the Educational Practice course chose to use a form of 'backward mapping'. By backward mapping, we refer to the process of identifying the required competencies that fourth year preservice teachers need to attain by the completion of their training as outlined by MRTEQ, and then developing the programme retrospectively from the fourth year B.Ed course to the third, second and first year course outcomes. This approach develops the programme design and teaching and assessment methods by focusing on the desired learning outcomes that pre-service teachers should have attained before beginning their teaching career, aligning the fourth year course activities to meet these requirements, and then developing the preceding years accordingly.

Further in the consideration of the design of the programme was the need to take into account the diversity of students in HEIs, and specifically, the nature of the student who enrolls at UWC. Biggs ${ }^{3}$ states that the challenges of working with the diversified nature of the student population in HEIs often means that many students struggle with the requirements and expectations of higher education learning. This aspect is especially prevalent within the UWC student population, many of whom come from disadvantaged school contexts which have not adequately prepared them for the rigors of tertiary

1 John Biggs, "Constructive Alignment in University Teaching," HERDSA Review of Higher Education 1 (2014), 5-22.

2 Department of Basic Education, National Qualifications Framework Act (67/2008): Revised Policy on the Minimum Requirements for Teacher Education Qualifications (Pretoria, 2015).

3 John Biggs, "What the Student Does: Teaching for Enhanced Learning," Higher Education Research \& Development 31, no. 1 (2012): 39-55. 
studying. Biggs ${ }^{4}$ goes on to note that given these challenges it is necessary to think carefully about how an institute develops a technology of teaching that engages and supports all students to be successful in the learning processes.

This article begins by situating the debate within teacher education and includes a discussion on the use of the constructive alignment approach in designing teaching and assessment practices within the ITE programmes at UWC. This provides the necessary outline for the discussion that follows that describes the UWC university context, the B.Ed programme specifically focusing on the fourth year course (EDC 401), and the challenges involved in adapting the current $\mathrm{B}$.Ed programme given the type of student who registers to study at UWC. This is followed by a discussion on how the course was re-developed with a focus on constructive alignment by describing preservice teacher competences, developing the Intended Learning Outcomes (ILOs) and linking these to the teaching and assessment tasks. The final section of the article reflectively discusses the newly developed course in terms of the challenges involved in the re-design process.

\section{Setting the context}

\section{II.1. Institutional context}

According to the UWC strategic plan, the historical location of the university can be classified as a Historically Black Institution (HBI). ${ }^{5}$ The profile of the UWC student is mainly working class and many of the students come from schools in disadvantaged communities where they often receive an inferior education that does not adequately prepare them for their university studies. An important focus, therefore, within the re-design of the ITE programme at UWC, was that it placed an emphasis on students initially spending more time during their studies on theoretical aspects of ITE in order to distantiate them from their own experiences of schools and education. This process is what the literature refers to as an 'apprenticeship of observation' ${ }^{67}$

${ }^{4}$ John Biggs, "What the Student Does: Teaching for Enhanced Learning," Higher Education Research \& Development 31, no. 1 (2012): 39-55.

${ }^{5}$ University of the Western Cape, Charter of Graduate Attributes and Strategic Plan for Teaching and Learning (Cape Town, 2009), 5.

${ }^{6}$ Dan Lortie, Schoolteacher: A sociological study (Chicago: University of Chicago Press, 1977).

${ }^{7}$ Pamela Grossman, "Overcoming the apprenticeship of observation in teacher education coursework," Teaching and Teacher Education 7, no. 4 (1991): 345-357. 
What this literature makes reference to, is that unless students are exposed to alternative ways of thinking about the teaching and learning process, they will tend to reproduce the way in which they themselves experienced education during their schooling. As many UWC students were not exposed to good quality and varied learning experiences during their schooling, it is necessary for the B.Ed programme to ensure that the students are exposed to theory on teaching and learning scenarios beyond their own schooling experiences. Grossman ${ }^{8}$ notes, that these deeply ingrained 'apprenticeship of observation', i.e. the way in which the students have observed teaching and learning to take place prior to their entry into the university, needs to be challenged.

Drawing on the 'apprenticeship of observation' understanding, the education practice faculty staff at UWC felt that exposing students to more theory during the early stages of their degree completion would assist to provide new and alternate educational knowledge to ameliorate their prior schooling experiences as a learner. This focus would require that additional support be provided during the B.Ed programme to guide the students to interpret the new theoretical knowledge and educational concepts in the course. Within UWC this is particularly important as highlighted by the pilot National Benchmarking tests conducted at UWC in 2009 that tested a sample of students in the areas of Academic Literacy and Mathematics and categorised students into three domains of proficient, intermediate and basic bands. The outcome of the tests indicated that many UWC students fall into the 'basic band' of proficiency and thus require programmes which offer a great deal of learning support in order for them to achieve a quality degree in a reasonable time period. What this means for many students enrolling at UWC, is that they may require additional time for their induction into academic literacy at the university if they are to succeed, and further, without this support, student throughput may be severely affected. This issue is supported by the fact that the university output statistics show that there is a significant attrition rate of students entering the courses to students graduating. Some of these factors may include, (1) students dropping out because they are not coping with the course, (2) financial constraints, (3) lack of support from parents, university staff, peers, and (4) lack of support from the system, i.e. the university teaching not supporting the students' learning.

Focusing on finding ways to support the students from within the university system was an important component when considering the redesign of the B.Ed programme. Academic staff development with regard to

${ }^{8}$ Pamela Grossman, "Overcoming the apprenticeship of observation in teacher education coursework," Teaching and Teacher Education 7, no. 4 (1991): 345-357. 
teaching and learning - theories of learning, curriculum alignment, teaching strategies, assessment and quality assurance - in this regard is essential. ${ }^{9}$ For improved throughput within the B.Ed programme in the UWC context, therefore, a different conception of teaching and learning is required. With this in mind, a structured approach to course and programme design within the B.Ed programme, one that would be of benefit to the student learning experience and the faculty teaching programme at UWC, was envisaged. The focus of the new programme would be on developing a programme that could guide course development for optimal teaching and learning within the specific requirements of the profile of the MRTEQ document and the student who enrolls at UWC.

\section{II.2. The re-design context}

In order to consider the way forward in the B.Ed course re-design, the author of the article attended a course offered by the Tuning Academy that focused on the design and implementation of HEIs quality qualifications. The Tuning Academy is an international institution that focuses on matters relating to teaching and learning processes in higher education. The author of this article was invited to take part in the 'Tuning Africa' programme that offers a network of communities of academic experts who meet together to discuss and collaborate around teaching and learning instruments with a focus on designing new programmes or adapting existing programmes as required within their higher institution.

The first phase of the Tuning Africa pilot project was implemented from 2011-2013 and included sixty different universities in Africa. Different groups focused on five subject areas, one of which was teacher education. The aim was for the participants in the course to share knowledge and experiences in order to develop curricula that was tailored to meet the unique needs specific to the subject discipline and HEI context. The outcome of the author's involvement in this experience was the re-design of the UWC's B.Ed four year programme. The B.Ed programme at UWC focuses on the Senior Phase of schooling and prepares pre-service teachers to teach at schools in Grades 7-9, working with children between the ages of 13-15 years old. The author chose to focus specifically on the Education Practice (EDC 401) aspect of the fourth year B.Ed course as this is a core course module of the programme.

9 Council on Higher Education, Council on Higher Education 2007-2008 Annual Report (Pretoria, 2008). 


\section{II.3. The ITE curriculum}

The ITE curriculum in South Africa has evolved from the first national policy governing the provision of teacher education, the Norms and Standards for Educators (Department of Education, 2000), that stipulates that ITE programmes should prepare prospective teachers for seven different 'roles of the educator'. This was expanded in the MRTEQ policy document that states that by the end of their ITE, qualifying teachers should have achieved ten exit level outcomes, verified against a set of eighty-nine assessment criteria. ${ }^{10}$ The publication of the MRTEQ document has thus impacted on South African teacher educators who have found themselves grappling with how to re-organise coursework and practicum expectations around the fairly extensive lists of discrete roles, outcomes and competences found in the document. ${ }^{11}$ As a result many HEIs are currently adapting or re-designing their ITE programmes to meet the requirements of the MRTEQ document.

Alongside the programme development of ITE, there are macro-factors considerations beyond the faculty level, like institutional-level and government-level requirements. For instance, the current trend in higher education both internationally and nationally is to improve access and outcomes of all university students. Diverse students from varying backgrounds have access to higher education, and university classrooms are no longer occupied by students who are only economically privileged and the academically elite. ${ }^{12}$ What this means, is that the learning environment and interaction with the students in lecture rooms within HEIs needs to be adapted to the needs of the diverse student demographics and thus the variable levels of support that the students require. ${ }^{13}$ Devlin and Samarawickrema ${ }^{14}$ suggest that in the past, a high challenge/low support

${ }^{10}$ Lungi Sosibo, Willie Van Vollenhoven, Lee Rusznyak, and Robert Balfour, "Why academic depth and rigour in university-based coursework matters for prospective teachers," Perspectives in Education 34, no. 1 (2016): 1-9.

${ }^{11}$ Roy Killen, Nieman M, and Fraser William, "Issues in competence and pre-service teacher education. Part 2: the assessment of teaching practice," South African Journal of Higher Education 19, no. 2 (2005): 246-259.

${ }^{12}$ Helen Larkin and Richardson Ben, "Creating high challenge/high support academic environments through constructive alignment: student outcomes," Teaching in higher education 18, no. 2 (2013): 192-204.

13 John Biggs, "What the Student Does: Teaching for Enhanced Learning," Higher Education Research \& Development 31, no. 1 (2012): 39-55.

${ }^{14}$ Marcia Devlin and Samarawickrema Gayani, "The criteria of effective teaching in a changing higher education context," Higher Education Research \& Development 29, no. 2 (2010): 111-124. 
learning environment was considered desirable, but in order to accommodate the changes in student demographics, a high challenge/high support environment is necessary. Consequently, with the massification and internationalisation of higher education, there is a corresponding change in requirements at the institutional and governmental level. Thus, there is pressure for universities to re-define and demonstrate effective teaching for a broader range of students and for the faculties within universities to re-align their programmes to meet the macro-needs of the country.

Higher education in South Africa is following a similar trend. In South Africa, the history of teacher education emulates the international educational landscape, with broader access to schools and universities changing the demographics of the institutions within an evolving learning environment. A fundamental challenge for schools is to find teachers who can develop their learners within a multicultural, multilingual and integrated classroom learning environment. This in turn impacts on ITE programmes because the challenge is to design curricula with selected knowledge and skills - recontextualising principles $-{ }^{15}$ that offer powerful teacher training in the limited time available. The aim of this study was to re-design a final year course within a B.Ed programme using the constructive alignment approach guided by Biggs' framework. ${ }^{16}$ This approach guides the development and alignment of key teaching and assessment dimensions of a programme to meet the desired outcomes of a course. The course re-design discussed in this article focused on aligning the B.Ed programme at UWC to consider the acquisition, integration and application of knowledge in the ITE programme drawing on the institutional requirements as well as the competencies as outlined in the MRTEQ policy document.

\section{A Constructive Alignment approach to programme re-design}

Biggs ${ }^{17}$ argues that constructive alignment is an approach that is appropriate for guiding the design process of adapted curriculum courses as it embraces the whole system, taking into account the departmental, institutional and classroom levels. His framework encourages a system of

15 Basil Bernstein, Class, Codes and Control, vol. 3: Towards a Theory of Educational Transmissions (London: Routledge, 1975).

16 John Biggs, "What the Student Does: Teaching for Enhanced Learning," Higher Education Research \& Development 31, no. 1 (2012): 39-55.

17 John Biggs, "What the Student Does: Teaching for Enhanced Learning," Higher Education Research \& Development 31, no. 1 (2012): 39-55. 
curriculum design that optimises the conditions for quality learning where all aspects of teaching and assessment are aligned to support high level learning. Accordingly, the move toward a system where the design of the teacher education programme is aligned to the needs of the students is likely to encourage all students, and not only the 'academic' students, to use higherorder learning processes. Grossman ${ }^{18}$ and Lancaster and Auhl ${ }^{19}$ argue that teacher education programmes within the international education context often involve uncoordinated knowledge-centred courses that do not align with the requirement of the 'field experiences' of initial teacher education (ITE). The challenge, therefore, for teacher educators, is to align the ITE programmes and courses to cater for the theoretical and practical growth of diverse students while meeting the ITE policy requirements.

In order to teach for enhanced learning, Biggs ${ }^{20}$ suggests a constructive alignment (CA) framework to help teachers reflect on what they are doing. According to Cain and Woodward, ${ }^{21} \mathrm{CA}$ is a student-centred model of education that aims to enhance learning through the amalgamation of constructivism and aligned curriculum. CA involves the following three steps: $:^{22}$

- To align teaching objectives

- To use teaching methods to realise these objectives

- To use assessment tasks to address the objectives to test whether students have learned what the objectives state they should be learning

The principle of CA involves clearly stating what the outcomes of the intended teaching are, that is, what the student will be able to do at the end of the course. ${ }^{23}$ This is expressed as the Intended Learning Outcome (ILO) and requires course or curriculum developers to devise Teaching Learning

${ }^{18}$ Pamela Grossman, "Overcoming the apprenticeship of observation in teacher education coursework," Teaching and Teacher Education 7, no. 4 (1991): 345-357.

19 Julie Lancaster and Auhl Greg, "Encouraging pattern language development in a preservice inclusive education course: A comparative study," International Journal of Disability, Development and Education 60, no. 4 (2013): 363-381.

${ }^{20}$ John Biggs, "Enhancing teaching through constructive alignment," Higher education 32, no. 3 (1996): 347-364.

${ }^{21}$ Andrew Cain and Woodward Clinton, "Toward constructive alignment with portfolio assessment for introductory programming," Teaching, Assessment and Learning for Engineering (TALE), (2012 IEEE International Conference): 1-11.

${ }_{22}$ John Biggs, "What the Student Does: Teaching for Enhanced Learning," Higher Education Research \& Development 31, no. 1 (2012): 45.

${ }^{23}$ John Biggs and Tang Catherine, Designing intended learning outcomes (England: Open University Press, 2007), 113-132. 
Activities (TLAs) that require the students to actively construct meaning from the knowledge and learning they are presented with during the study programme. Programme ILOs are derived from several sources, but essentially they must align with attributes of the ideal graduate from the university, the faculty and professional bodies of their course discipline. In the South African education context this would for example refer to the requirements of the specific HEI, the education faculty and specific department within the faculty and the MRTEQ policy document. In order to achieve these ILOs the CA approach suggests that the general aims of the programme should be listed in five or six statements which are then converted into programme ILOs. This is best accomplished by incorporating verbs such as 'design', 'reflect', 'hypothesise', 'generate', and so forth. The focus here is on supporting the expository focus of lectures with actual tasks where the student is required to do authentic tasks related to their learning.

\section{Developing the Course}

\section{IV.1. Initial foundations of EDC 401}

At UWC, our goal is to prepare a holistic pre-service teacher with a balance of theoretical, practical and affective attributes. Given the complexity of teaching, there are a multitude of concepts and techniques important for pre-service teachers to learn within a programme. On the one hand, programmes can give the students exposure to a multitude of theories, tips, techniques, concepts, skills and practices. But including all of the concepts in the programme is likely to result in an overcrowded and fragmented curriculum. The programme, therefore, should be designed to include a mix of knowledge and skills that develops the pre-service teachers towards attaining the requirements as encapsulated within the MRTEQ document by the end of the programme.

\section{IV.2. Structure of EDC 401 within the B.Ed Programme at UWC}

The course that is the focus of this article is located within the B.Ed programme comprising of a total of 480 credits. There are approximately 1500 students within a cohort. The course Educational Practice (EDC) is developmental, from the first year (EDC 101) to the fourth year (EDC 401), with the accompanying number of credits (see Figure 1). This course is a 
compulsory full-time course for fourth year education students (EDC 401), and is defined by 60 credits. On average 250 students complete this course each year. This is a core course which means that if students fail the course they will have to repeat the entire year of study.

\section{CONTEXT OF RE-DESIGNED COURSE}

\section{BACHELOR OF EDUCATION (BEd)}

480 Credits

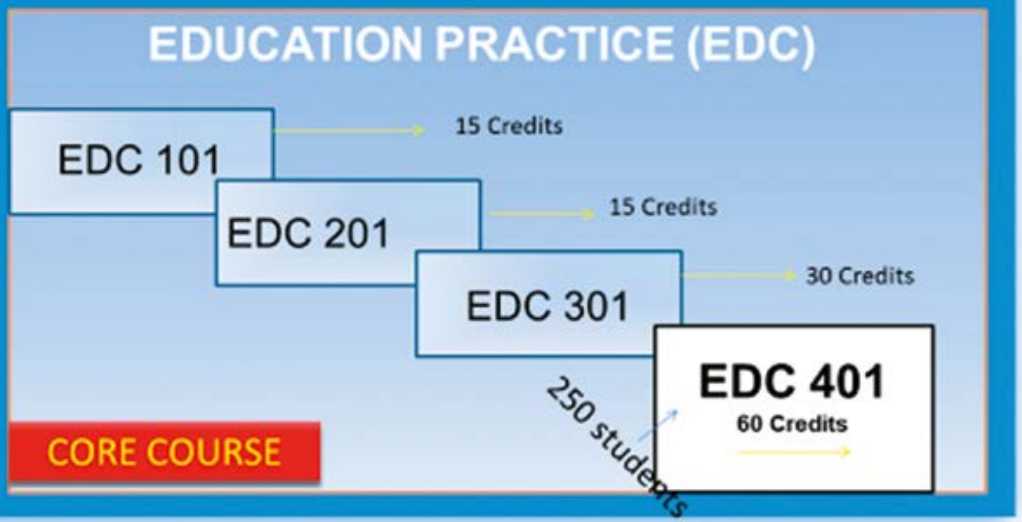

Figure 1

Credits accumulated over the EDC four year programme

The four year Education Practice (EDC) programme at UWC was designed to develop a conceptually coherent and contextually responsive curriculum. In the first year (EDC 101) and the second year (EDC 201), the knowledge that is selected aims to provide theoretical and disciplinary knowledge to give the pre-service teachers the conceptual tools to analyse and reflect on their educational assumptions from their own schooling experiences, as to what constitutes effective teaching and learning. Importantly, as discussed previously, the initial two years of the teaching programme also attempts to distantiate the pre-service teachers from the experientially-acquired norms of teaching experienced in their own schooling. Many UWC students enter their first year university programme coming 
from largely dysfunctional schooling systems, where pervasive practices like insufficient engagement with conceptual knowledge and use of corporal punishment could be considered normal in their practice. ${ }^{24}$

In order to interrupt the students' perception of how schooling takes place, the UWC programme was designed to provide the student teachers in their initial two years of teacher training with the theoretical and conceptual knowledge of good teaching practices before exposing them to school sites. For this reason the teaching practice aspect of the B.Ed programme is designed to minimise the student teachers' school contact to two weeks of classroom observation only in their $2^{\text {nd }}$ year of studying. It is hoped that by providing the students with a new theoretical and conceptual lens during their course work, this will enable them to re-consider or re-conceptualise aspects of teaching and learning before they begin the practical aspect of the B.Ed programme. The theoretical and conceptual components of the B.Ed programme are therefore structured in a specific manner to support this. In the students' first and second year in the B.Ed programme, they are equipped with theory that they can then begin to apply in practice during their third and fourth year.

In the third (EDC301) and fourth (EDC401) year of the B.Ed programme, the selection of relevant knowledge is organised around principles that foreground situational and practical knowledge as it is envisaged that by this time the students should be able to use the theoretical and conceptual tools that they have been provided during their first two years of studying, to adapt their teaching to varied and diverse school contexts. The thinking behind this approach is that by providing pre-service teachers, specifically those who completed their schooling in dysfunctional or disadvantaged school contexts, with the necessary conceptual tools prior to the commencement of the practical component of their training, allows them to use a more theoryinformed approach when faced with the limitations and structural constraints found in different school context. Attempts to prepare pre-service teachers for specific contexts are more likely to entrench rather than alleviate inequalities, as the emphasis is on contextual relevance and not the powerful knowledge that enables teachers (and their learners) to participate in nationally important conversations that transcend local contexts..$^{25}$ Programmes that prepare pre-service teachers, via a theory-informed

${ }^{24}$ Brahm Fleisch, Primary education in crisis: Why South African schoolchildren underachieve in reading and mathematics (Cape Town: Juta, 2008).

${ }^{25}$ Michael Young, "From constructivism to realism in the sociology of the curriculum," Review of research in education 32, no. 1 (2008): 1-28. 
approach for diverse teaching contexts, thus move away from giving teachers only survival tips and coping skills for teaching in contexts, which is argued to be anti-intellectual.

\section{IV.3. Competences}

The influences of many systems shape the development of a programme, particularly at three levels, national competences, university competences and faculty competences. National competences are shaped by the requirements of the national curriculum and policy requirements. University competences are shaped by the requirements of the university, particularly the graduate attributes as espoused by the university. Faculty requirements are shaped by the experts in the specific faculty and, as in the case of the B. Ed programme, the faculty staff's view of education. The development of new or adapted programmes must therefore be carefully scaffolded to take all levels of competence into account starting from a foundation national competences (curriculum and policy), university competences (graduate attributes), faculty competences (requirements of the programme), and finally departmental competences (if different from the faculty). In the South African teacher education context the national curriculum is framed by the MRTEQ document, the graduate attributes are outlined in the UWC strategic plan, the faculty competences and rules for the course are outlined in the UWC year book, and the departmental competences are specific to the course as provided in the course outline. All these competences must integrate in order to develop a successful UWC teacher graduate.

\section{IV.4. Minimum Requirements for Teacher Education Qualification (MRTEQ)}

The first curriculum policy for teachers in South Africa was the Norms and Standards for Educators document ${ }^{26}$ which introduced seven interrelated roles for teachers as key criteria for the development of teacher qualifications. With the input of key stakeholders in South African education the policy was subsequently strengthened and the revised MRTEQ document was published by the minister of Higher Education and Training in the Government Gazette No 38487 on the 19 February 2015. The MRTEQ

${ }^{26}$ Department of Basic Education, Norms and Standards for Educators (Pretoria, 2000). 
specifies a set of minimum requirements for teacher education to ensure that the higher education system produces teachers of quality in line with the needs of the country. To promote the development of teachers with strong conceptual and contextual-driven teaching, the MRTEQ promotes various types of knowledge that must underpin teachers' practice, while encapsulating all of these in the notion of integrated and applied knowledge for teacher education. ${ }^{27}$ The focus of the integrated and applied knowledge is that it enables teachers to be able to draw on a reservoir of knowledge, mixing the theoretical and practical, to guide their decisions in the moment of practice. This focus places an emphasis on the 'what' and 'how' of learning with careful scrutiny of which knowledge should guide one's action within a given moment of practice. Further, the ideal is that reflection, connection of various knowledge and synthesis of knowledge and practice should be foregrounded in every decision made. To this end, the MRTEQ describes clear and specific requirements for the development of teacher education learning programmes, as well as guidelines regarding practical and Work Integrated Learning (WIL) structures. MRTEQ specifies that different types of knowledges that are required for the acquisition, integration and application of knowledge for teaching purposes, listing them as: disciplinary learning, pedagogical learning, practical learning, fundamental learning and situational learning. These five types of learning and knowledge should provide the basis of the curriculum, with different minimum credits assigned to a specific course throughout the programme. Each of these knowledge areas within ITE are important in order to develop a conceptually coherent and contextually responsive teacher. ${ }^{28}$

For the purposes of the current re-designed course (EDC 401) at UWC, the focus was on ensuring that the B.Ed programme integrated the mix of knowledge as required by MRTEQ, as well as making certain that the practical aspects of the course, namely the practical and situational knowledge component of teaching practice, and to a lesser extent the integration of Information and Communications Technology (ICT) in fundamental learning and knowledge component, were included in the module. These knowledge components are described and the role that they play in teacher education discussed.

27 Department of Basic Education, National Qualifications Framework Act (67/2008): Revised Policy on the Minimum Requirements for Teacher Education Qualifications (Pretoria, 2015), 10-11.

${ }^{28}$ Lungi Sosibo, Van Vollenhoven Willie, Rusznyak Lee, and Balfour Robert, "Why academic depth and rigour in university-based coursework matters for prospective teachers," Perspectives in Education 34, no. 1 (2016): 1-9. 
Firstly, practical knowledge is the condition for the development of tacit knowledge, which is an essential component of learning to teach. ${ }^{29}$ This type of knowledge can be described in two parts of learning, namely, learning from practice and learning in practice. Learning from practice includes the study of practice mainly in university lectures, for instance, analysing contexts, videos, lesson observations, and so forth. On the other hand, learning in practice is the teaching practice period at schools, including aspects of learning from practice, for example, teaching in the classroom, observing lessons and reflecting on lessons by other students. Secondly, situational knowledge is knowledge of varied situations, contexts and environments of education (for example, the classroom, schools, communities, districts). Studying education in different social contexts allows the preservice teachers to understand the nature and complexity of society and the diverse challenges faced by various school contexts. Finally in fundamental knowledge the focus was on learning to use ICT's as a tool in classroom teaching and learning. The mix of these knowledges, therefore, provides a basis for the design of the curriculum for EDC 401, the practical component of the B.Ed programme, and these are considered together with the minimum set of competences required from a newly qualified teacher in the re-design of the course.

Table 1 below provides an outline of how the various learning outcomes, graduate attributes and assessment tasks for the EDC 401 were aligned taking into account the requirements of the course from the MRTEQ policy document, as well as the university, faculty and departmental requirements for the programme.

\section{Proposal for the Revised B.Ed Course}

\section{V.1. Mapping the MRTEQ Competences into the B.Ed programme}

In order to start the process of re-designing the EDC 401 course the author examined the various levels of competences in required for the UWC graduate attributes, faculty competences and the MRTEQ policy document. First, the department faculty reflected on the current programme at UWC and our current practices as lecturers within the programme.

29 Department of Basic Education, National Qualifications Framework Act (67/2008): Revised Policy on the Minimum Requirements for Teacher Education Qualifications (Pretoria, 2015), 12. 


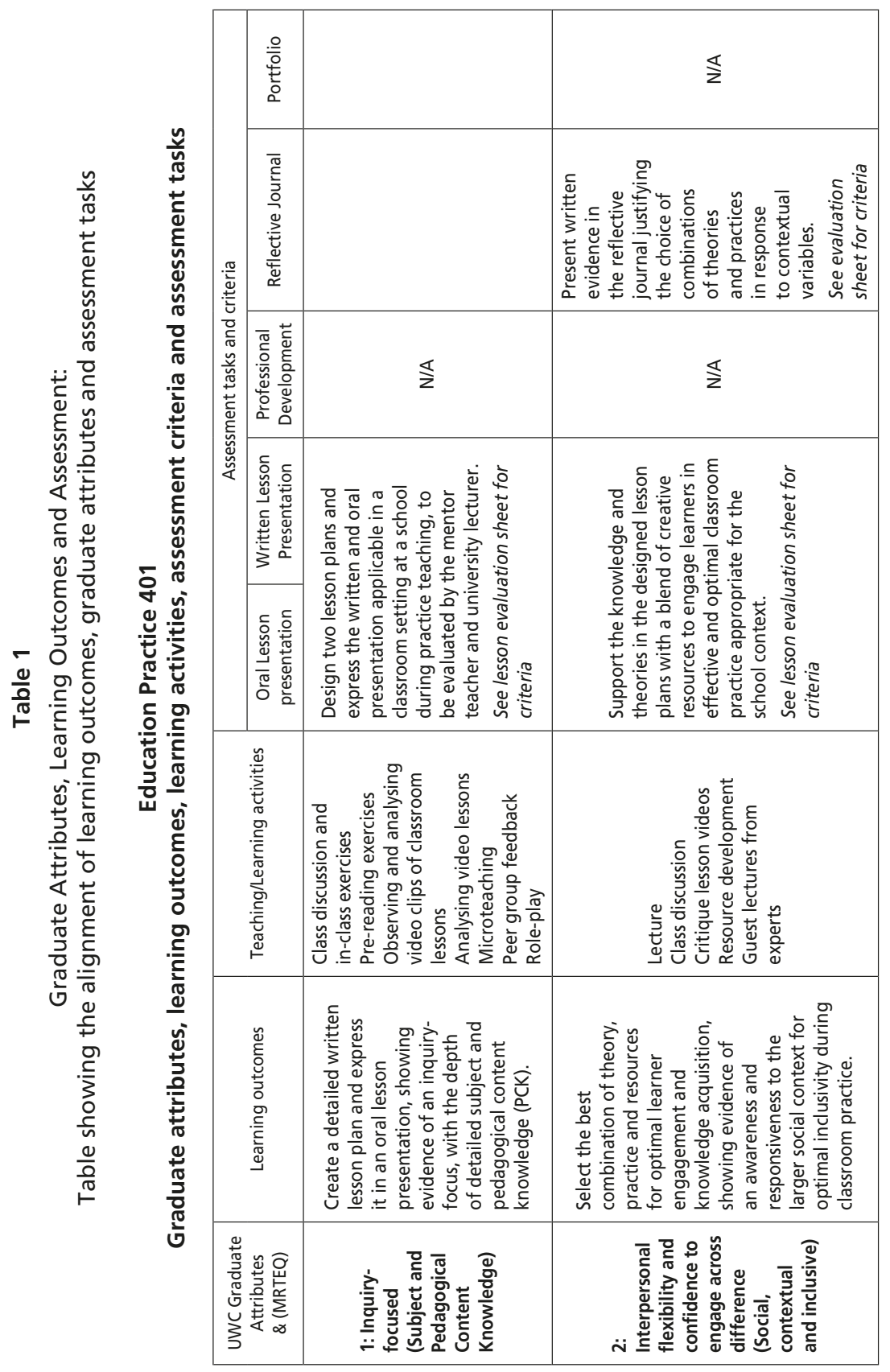

Tuning Journal for Higher Education 


\begin{tabular}{|c|c|c|c|c|c|}
\hline \multirow{5}{*}{ 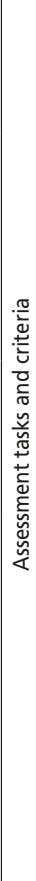 } & $\begin{array}{l}\frac{.}{\bar{O}} \\
\frac{\mathrm{t}}{\circ} \\
\frac{0}{2}\end{array}$ & $\stackrel{t}{z}$ & $\stackrel{\mathbb{z}}{\mathbf{z}}$ & $\stackrel{\leqslant}{z}$ & 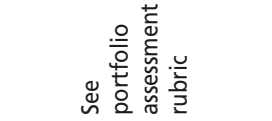 \\
\hline & 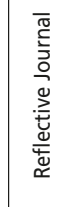 & 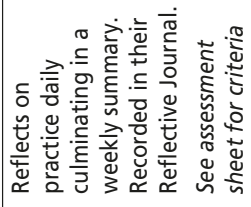 & $\stackrel{\pi}{z}$ & 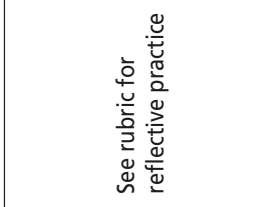 & 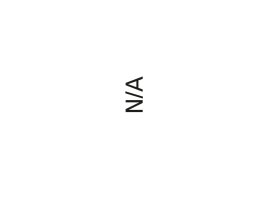 \\
\hline & 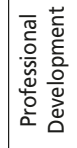 & $\stackrel{4}{z}$ & $\stackrel{4}{\Sigma}$ & $\stackrel{4}{z}$ & 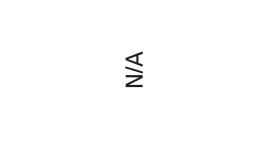 \\
\hline & 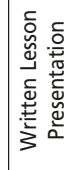 & $\stackrel{5}{\mathbf{z}}$ & $\stackrel{t}{z}$ & 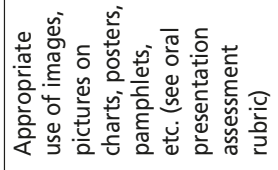 & 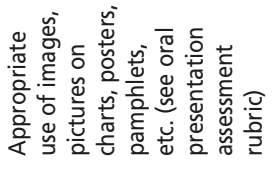 \\
\hline & 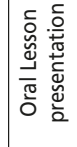 & $\stackrel{\nwarrow}{\Sigma}$ & 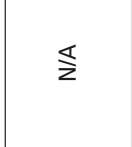 & 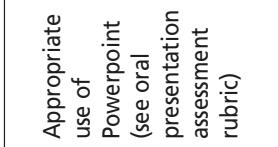 & 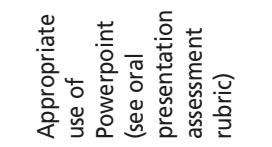 \\
\hline & 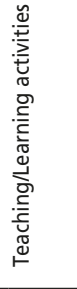 & 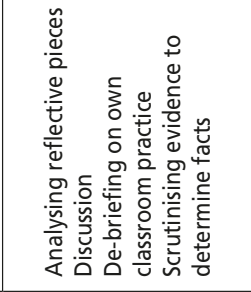 & 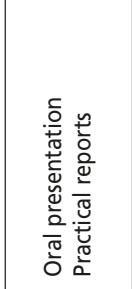 & 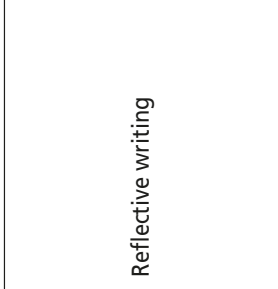 & 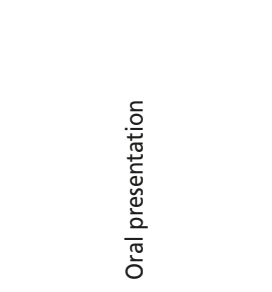 \\
\hline & 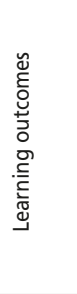 & 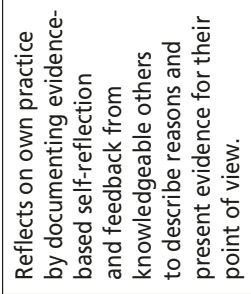 & 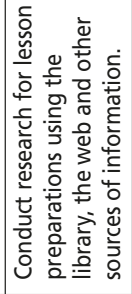 & 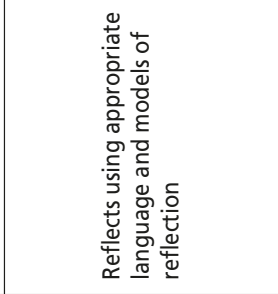 & 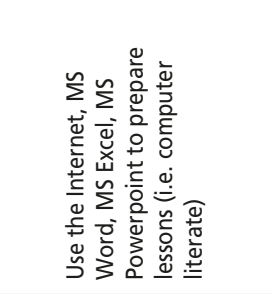 \\
\hline & 焉 & 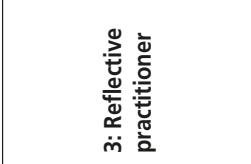 & & 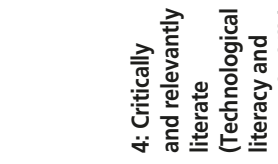 & \\
\hline
\end{tabular}




\begin{tabular}{|c|c|c|c|}
\hline \multirow{5}{*}{ 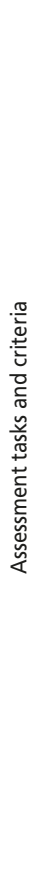 } & $\begin{array}{l}\frac{\circ}{\overline{0}} \\
\stackrel{\stackrel{t}{0}}{\circ} \\
\frac{2}{2}\end{array}$ & 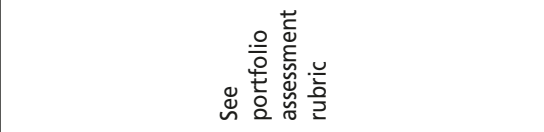 & 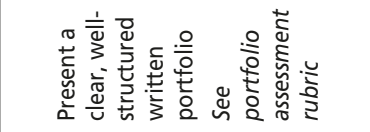 \\
\hline & 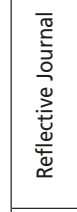 & 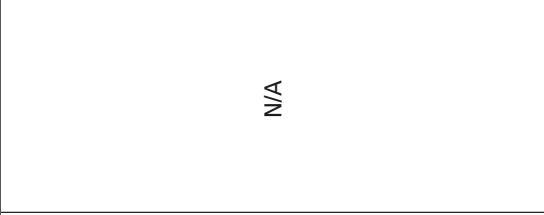 & 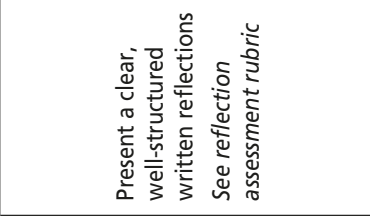 \\
\hline & 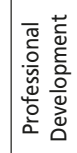 & 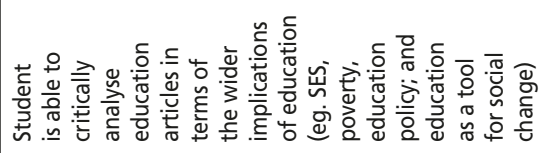 & 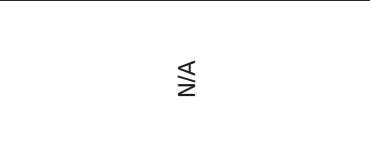 \\
\hline & 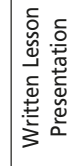 & 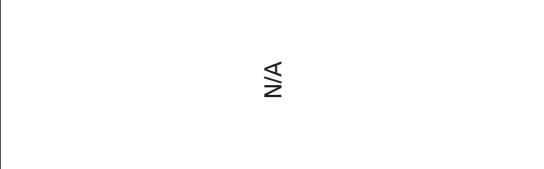 & 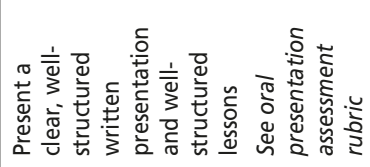 \\
\hline & 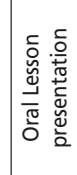 & 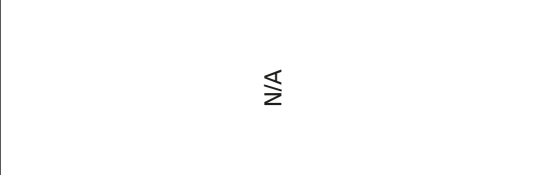 & 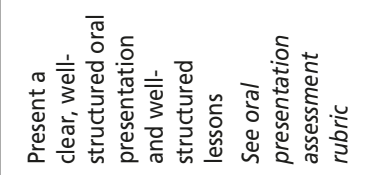 \\
\hline & 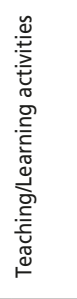 & 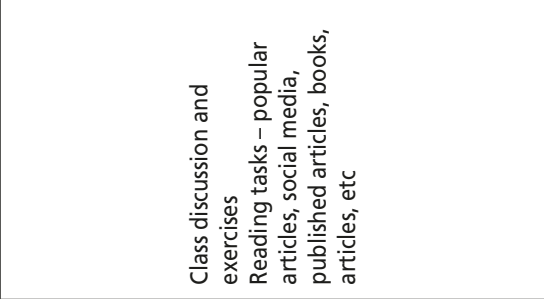 & 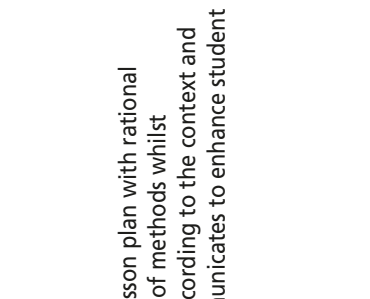 \\
\hline & 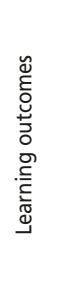 & 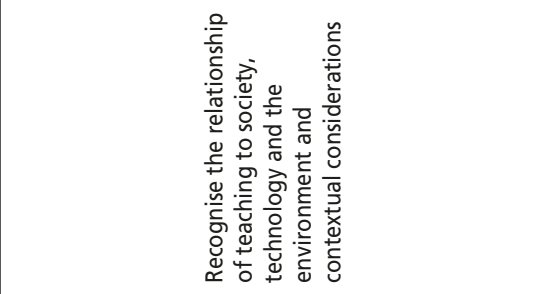 & 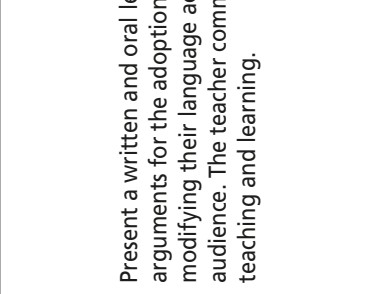 \\
\hline & 象 & 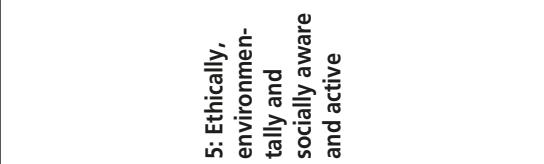 & 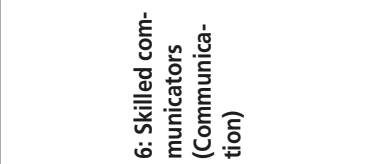 \\
\hline
\end{tabular}




\begin{tabular}{|c|c|c|c|}
\hline \multirow{4}{*}{ 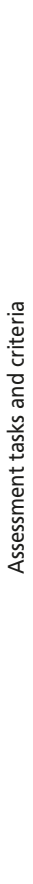 } & $\begin{array}{l}\frac{\circ}{0} \\
\stackrel{\circ}{ \pm} \\
\frac{0}{0}\end{array}$ & 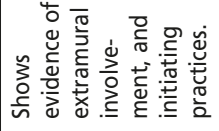 & 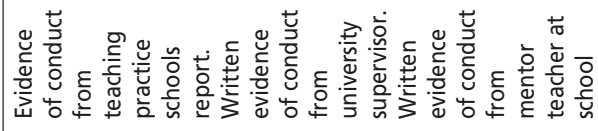 \\
\hline & 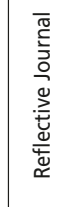 & 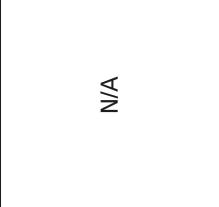 & $\$$ \\
\hline & 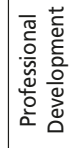 & $\stackrel{\$}{\Sigma}$ & $\$$ \\
\hline & 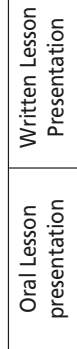 & 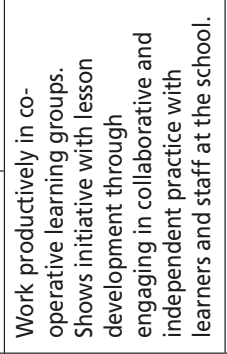 & 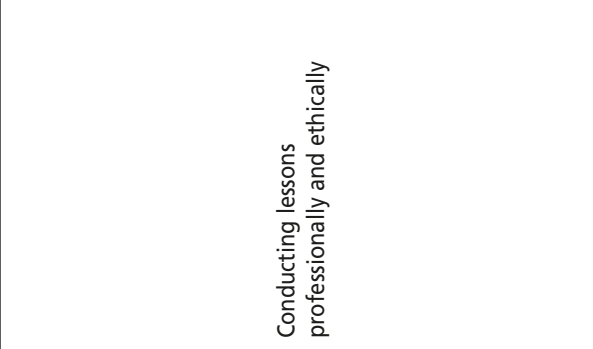 \\
\hline & 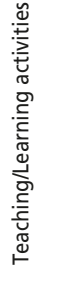 & 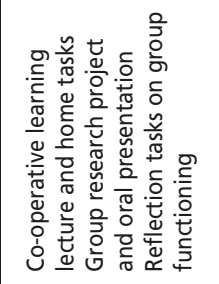 & 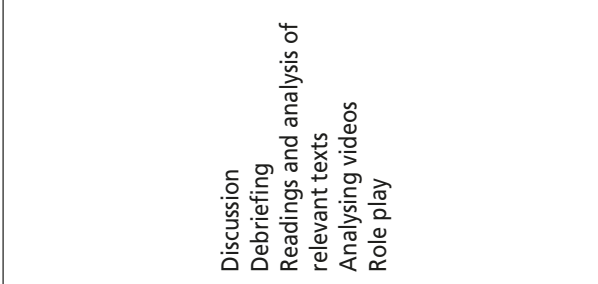 \\
\hline & 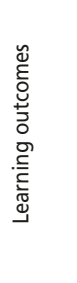 & 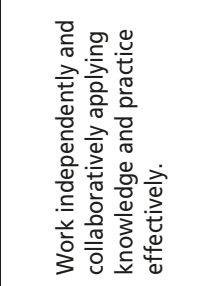 & 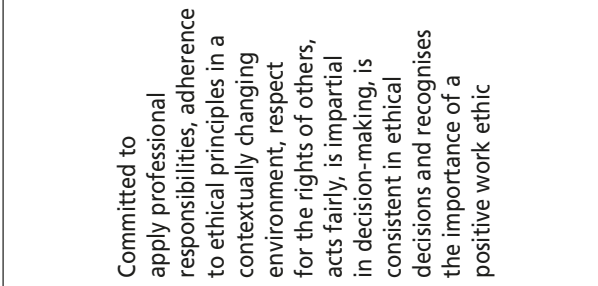 \\
\hline & : & 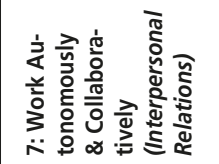 & 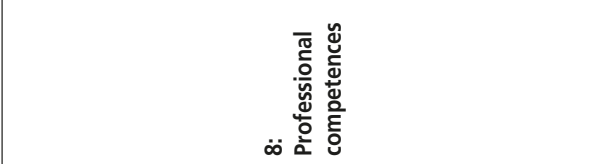 \\
\hline
\end{tabular}


Following this we developed the table presented in Table 1 above that aligned the graduate attributes of UWC and the Faculty of Education with learning outcomes of the MRTEQ document and the assessment tasks of the B.Ed programme.

The graduate attributes of UWC outlines eight competences for a student by the end of their undergraduate studies at UWC namely: inquiry-focused, interpersonal flexibility and confidence to engage across difference, reflective practitioner, critically and relevantly literate, ethically, environmentally and socially aware and active, skilled communicators, work autonomously and collaboratively, and professional competences (see Table 1 above). The Faculty of Education, drawing on the UWC student attributes then aligned these attributes with ITE competencies of the B.Ed programme. These competencies are in line with the eleven competences outlined in the MRTEQ document. ${ }^{30}$ As part of the re-design process the MRTEQ competencies were recontextualised into six competences (see Table 1) in the EDC 401 course based on the three knowledges that were foregrounded in the programme, namely, practical learning, situational learning and fundamental learning in ICT. Through the concept mapping and reflection on the course by the lecturers involved, and by combining and reconstructing the competences, a final eight attributes were established to describe the academic and practice requirements of a pre-service teacher at UWC. These were subject and pedagogical content knowledge, contextual practice, communication skills, reflective practitioners, critical teaching literacies and interpersonal relations, with an additional two key teaching competences that define the key roles of teachers-in-training, namely teacher reflection on practice and teacher professionalism in practice.

Figure 2 below indicates how the MRTEQ requirements align with the graduate competencies as defined by UWC and the Education Faculty. As noted, the re-design programme added in two additional competencies based on the UWC pre-service teacher outcome requirements of the B.Ed programme.

The first step in the programme re-design was to explicitly state the learning outcomes of a fourth year student in the EDC 401 Education Practice course. These were based on Blooms/Krathwohl Taxonomy. Biggs suggests that verbs are particularly useful markers for operationalising alignment between what we want the students to learn, what is taught to them

${ }^{30}$ Department of Basic Education, National Qualifications Framework Act (67/2008): Revised Policy on the Minimum Requirements for Teacher Education Qualifications (Pretoria, 2015), 64. 
ALIGNING MRTEQ \& GRADUATE COMPETENCIES

\begin{tabular}{|c|l|l|}
\hline & \multicolumn{1}{|c|}{ GRADUATE ATTRIBUTES } & \multicolumn{1}{c|}{ MRTEQ } \\
\hline 1 & Inquiry-focused and knowledgeable & $\begin{array}{l}\text { Subject and Pedagogical } \\
\text { Content Knowledge }\end{array}$ \\
\hline 2 & $\begin{array}{l}\text { Interpersonal flexibility and confidence } \\
\text { to engage across difference }\end{array}$ & Social, contextual and inclusive \\
\hline 3 & Reflective Practitioner & Additional \\
\hline 4 & Critically and relevantly literate & $\begin{array}{l}\text { Technological literacy and } \\
\text { research skills }\end{array}$ \\
\hline 5 & $\begin{array}{l}\text { Ethically, Environmentally and Socially } \\
\text { Aware and Active }\end{array}$ & Socially Aware and Active \\
\hline 6 & Skilled Communicators & Skilled communicators \\
\hline 7 & Autonomous and collaborative & Interpersonal Relations \\
\hline 8 & Professional teaching competencies & Additional \\
\hline
\end{tabular}

Figure 2

Re-designing the fourth year B.Ed course at UWC

and what assessment tasks are planned. ${ }^{31}$ The course content was then designed to align with these 'actions' in order to develop the students' competency in their teaching as a fourth year pre-service teachers. Thus the action verbs were used to operationalise the way in which the lecturers developed and taught the course content. Verbs are used in a similar way in Table 1, where the final year EDC 401 course is depicted as using high level verbs such as theorise, reflect, generate and apply. Practically speaking, we specify the verbs which describe the behaviours which we want students to enact in the context of the content discipline being taught, specifying levels of understanding that can be used for awarding grades. The Teaching and Learning Activities (TLA) are then developed to elicit those verbs as student outcomes, and they are also embedded in the assessment tasks.

According to Biggs ${ }^{32}$ the teaching and learning context of a programme should be set up so that students have every encouragement to react with

31 John Biggs, "What the student does: teaching for enhanced learning," Higher Education Research \& Development 31, no. 1 (2012): 39-55.

32 John Biggs, "What the student does: teaching for enhanced learning," Higher Education Research \& Development 31, no. 1 (2012): 39-55. 


\begin{tabular}{|c|c|c|}
\hline \multirow{6}{*}{ 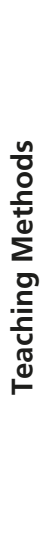 } & Lectures & $\begin{array}{l}\text { Traditional lectures have worked well in large group } \\
\text { settings }\end{array}$ \\
\hline & Tutorials & $\begin{array}{l}\text { Face-to-face interaction with the tutor and a more } \\
\text { personalized setting builds student's confidence }\end{array}$ \\
\hline & Discussion & $\begin{array}{l}\text { Of case studies, materials, videos, current affairs in } \\
\text { education }\end{array}$ \\
\hline & Practicals & $\begin{array}{l}\text { Student teachers spend } 7 \text { weeks at schools and apply } \\
\text { theory to practice during this time }\end{array}$ \\
\hline & Case studies & $\begin{array}{l}\text { Helps students analyze and apply theory to varying } \\
\text { contextual situations }\end{array}$ \\
\hline & $\begin{array}{l}\text { Self-directed } \\
\text { study }\end{array}$ & $\begin{array}{l}\text { Students do not like independent work, especially } \\
\text { independent PBL. But there is limited time to this. }\end{array}$ \\
\hline
\end{tabular}

Figure 3

Teaching and Learning activities in the B.Ed course

the level of cognitive engagement that the objectives require. The students should be helped to do what they need to do in order to meet the Intended Learning Outcomes (ILOs). ${ }^{33}$ In the B.Ed programme re-design, the first two ILOs are about 'applying', which require that the knowledge of theory of the course is learned and understood at a sufficient level by the student to create a detailed written lesson plan (Learning Outcome 1) by selecting theoretical concepts to teaching in contextually diverse environments. The programme suggests that this content is presented in class discussions, or through pre-reading activities, observation of video material, analysing texts and critiquing video material, lectures, and so forth (Learning Outcome 2). In Learning Outcome 3 the students are encouraged to reflect on their practice and teaching and learning activities applicable to their practice during de-briefing sessions after teaching practice, in-class reflections on written and video material, and through reflections on class or school teaching practice experiences that are recorded in their reflective journals.

Figure 3 presents some examples of Teaching and Learning Activities (TLAs) that were developed to prepare teachers for teaching practice in the course EDC 401. Through the use of lectures and tutorial the students should

33 John Biggs and Tang Catherine, Designing intended learning outcomes (England: Open University Press, 2007), 113-132. 
be exposed to a mix of activities such as group work, independent work, discussion and role-play, to name a few, in order that the students develop both academically and affectively.

\begin{tabular}{|l|l|}
\hline $\begin{array}{c}\text { Method } \\
\text { Lesson Plan } \\
\text { Presentation }\end{array}$ & $\begin{array}{l}\text { Rationale } \\
\text { Lesson plans will express their written design of the lesson, and will } \\
\text { be enacted in class. Part of these assessments will encompass the }\end{array}$ \\
\hline $\begin{array}{l}\text { Reflective } \\
\text { Journal }\end{array}$ & $\begin{array}{l}\text { Questions will be reflected on and written in their journal. Students } \\
\text { are encouraged to record learning-related incidences, and reflect on } \\
\text { them, whether presented in class activities of on teaching practice. }\end{array}$ \\
\hline Portfolio & $\begin{array}{l}\text { Portfolio will be used for students to collect and document evidence } \\
\text { of their experiences. Any resources developed or used in method } \\
\text { classes or while on teaching practice can be used. }\end{array}$ \\
\hline Professional & $\begin{array}{l}\text { Students' conduct and growth professionally will be encompassed in } \\
\text { practice and through their portfolio. }\end{array}$ \\
\hline Practice &
\end{tabular}

Figure 4

Proposed assessment methods for the B.Ed programme

Essential to any programme design is the necessity of the assessment activities being carefully aligned to the TLAs. Since the students are in their final year of study, the verbs used to describe the ILOs should depict a high cognitive level of learning in order to support their ongoing conceptual development of teaching. For instance the words reflect, apply, create should be used to develop the student's ability to apply new knowledge to practice. For the course EDC 401 it was necessary to ensure the alignment of the assessment tasks (ATs) with a focus on higher order thinking skills. In order to align assessments with teaching, the use of the following assessment tasks are envisaged: lesson plans (oral and written), reflective journal, portfolio and professional development. As the final aligning of the adapted B.Ed programme, the proposed assessment tasks are presented below in Figure 4.

\section{In conclusion}

Changing a programme such as the B.Ed programme at UWC is an iterative process. It requires deep and ongoing reflection on the part of all 
the faculty staff involved. Ensuring that the student competencies, the ILOs, teaching activities and student assessment align showed us the importance of clarity of expression when writing the ILOs and linking them to a competence. As a team we discovered that it was easier to align the course content moving from the outside, that is the university graduate attributes, moving inwards to align these with the faculty visions and course outcomes.

Making any changes to a programme is also a time consuming process that must involve collaboration and ongoing discussion by all those involved in the programme at all levels. It was necessary for all the staff members to work towards an agreement regarding the mix of competences and programme ILOs in order that the course content could be as cohesive as possible. Achieving agreement was not always easy and meeting regularly to reflect and discuss each step of the process was very challenging given the work commitments of the faculty staff. What was particularly helpful in providing the initial momentum to begin the process of changing the B.Ed programme was the demarcated time, and focus, for the staff to reflect, collaborate and discuss the programme and begin the planning of the adapted B.Ed programme to meet the requirements as outlined in the MRTEQ document. Notwithstanding, the biggest challenge throughout the process was staff challenges, especially teamwork and collaboration within the faculty. Though challenging, communication amongst staff members is pivotal to guide course and programme development. Communication should take place at all levels, from individuals, to departments, and with students themselves. Moreover, curriculum pacing, time on task, teaching and assessment activities are all factors that should be planned and communicated in faculty meetings throughout the year. Thus the challenge of collaboration amongst staff can be ameliorated through staff and student interactions, with both permanent and contract staff members - through planning and effective communication throughout the year.

What this article has aimed to provide is not a framework for the redesign of a programme, but a discussion on the journey that the faculty staff embarked on towards changing and adapting the B.Ed programme. The author of the article and education faculty are still involved in the ongoing changes to the B.Ed programme, and it is hoped that the article will engage education lecturers at various HEIs in a productive and ongoing discussion on aspects of adapting or changing teacher education programmes in order that we can ensure that our teachers going forward are excellently prepared for the complex world of schooling within the diverse South African context. 


\section{Bibliography}

Bernstein, Basil. Class, Codes and Control, vol.3: Towards a Theory of Educational Transmissions. London: Routledge, 1975.

Biggs, John. "Enhancing teaching through constructive alignment." Higher education 32, no. 3 (1996): 347-364.

—. "What the Student Does: Teaching for Enhanced Learning." Higher Education Research \& Development 31, no. 1 (2012): 39-55.

- "Constructive Alignment in University Teaching." HERDSA Review of Higher Education 1 (2014): 5-22.

Biggs, John, and Catherine Tang. Designing intended learning outcomes. England: Open University Press, 2007.

Cain, Andrew, and Clinton Woodward. "Toward constructive alignment with portfolio assessment for introductory programming." In Teaching, Assessment and Learning for Engineering (TALE), (2012 IEEE International Conference): 1-11.

Council on Higher Education. Council on Higher Education 2007-2008 Annual Report. Pretoria, 2008.

Department of Basic Education. Norms and Standards for Educators. Pretoria, 2000.

- National Qualifications Framework Act (67/2008): Revised Policy on the Minimum Requirements for Teacher Education Qualifications. Pretoria, 2015.

Devlin, Marcia, and Gayani Samarawickrema. "The criteria of effective teaching in a changing higher education context." Higher Education Research \& Development 29, no. 2 (2010): 111-124.

Fleisch, Brahm. Primary education in crisis: Why South African schoolchildren underachieve in reading and mathematics. Cape Town: Juta, 2008.

Grossman, Pamela. "Overcoming the apprenticeship of observation in teacher education coursework." Teaching and Teacher Education 7, no. 4 (1991): 345-357.

Killen, Roy, Marietha Nieman, and William Fraser. "Issues in competence and preservice teacher education. Part 2: the assessment of teaching practice." South African Journal of Higher Education 19, no. 2 (2005): 246-259.

Lancaster, Julie, and Greg Auhl. "Encouraging pattern language development in a pre-service inclusive education course: A comparative study." International Journal of Disability, Development and Education 60, no. 4 (2013): 363-381.

Larkin, Helen, and Ben Richardson. "Creating high challenge/high support academic environments through constructive alignment: student outcomes." Teaching in higher education 18, no. 2 (2013): 192-204.

Lortie, Dan. Schoolteacher: A sociological study. Chicago: University of Chicago Press, 1977.

Sosibo, Lungi, Willie Van Vollenhoven, Lee Rusznyak, and Robert Balfour. "Why academic depth and rigour in university-based coursework matters for prospective teachers." Perspectives in Education 34, no. 1 (2016): 1-9.

University of the Western Cape. Charter of Graduate Attributes and Strategic Plan for Teaching and Learning. Cape Town, 2009: 5. 
Young, Michael. "From constructivism to realism in the sociology of the curriculum." Review of research in education 32, no. 1 (2008): 1-28.

\section{About the author}

Dr. MELANIE B.LUCKAY (mluckay@uwc.ac.za) is a senior lecturer in the Faculty of Education at the University of the Western Cape, Cape Town, South Africa. She has a $\mathrm{PhD}$ in Science Education obtained at the University of Cape Town (UCT). She was a postdoctoral fellow at the Centre for Research in Engineering Education (CREE) at UCT. Her current role for the past six years as a faculty member at the University of the Western Cape is the teaching practice coordinator and academic teaching in the area of Education Practice. Her research focus is in science education, learning environment research, technological literacy and technology education, and she links her research to teaching practice with a link to socio-economic issues affecting education. 


\title{
The re-design of a fourth year Bachelor of Education programme using the Constructive Alignment Approach
}

\author{
Melanie B. Luckay
}

doi: http://dx.doi.org/10.18543/tjhe-6(1)-2018pp143-167

Received: 02.08 .2018

Accepted: 31.10 .2018

\section{Copyright}

Copyright for this article is retained by the Publisher. It is an Open Access material that is free for full online access, download, storage, distribution, and or reuse in any medium only for noncommercial purposes and in compliance with any applicable copyright legislation, without prior permission from the Publisher or the author(s). In any case, proper acknowledgement of the original publication source must be made and any changes to the original work must be indicated clearly and in a manner that does not suggest the author's and or Publisher's endorsement whatsoever. Any other use of its content in any medium or format, now known or developed in the future, requires prior written permission of the copyright holder. 